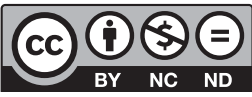

Estudos Teológicos foi licenciado com uma Licença Creative Commons Atribuição - NãoComercial - SemDerivados 3.0 Não Adaptada

http://dx.doi.org/10.22351/et.v60i2.4094

\title{
Ponderações críticas acerca da Covid-19: CONTRIBUIÇÕES PARA AMPLIAR O ENTENDIMENTO NO CONTEXTO BRASILEIRO $^{1}$
}

\author{
Critical considerations about Covid-19:
}

contributions to extend understanding in the Brazilian context

\section{Celso Gabatz ${ }^{2}$ Rosângela Angelin ${ }^{3}$}

Resumo: Em tempos de Covid-19, vivemos a condição, nunca experimentada, do isolamento social. Ficar distante para, paradoxalmente, nos protegermos como grupo social. De certa forma, não é equivocado dizer que estar longe é um ato de cuidado e afeto. A pandemia vem nos desafiando nessa difícil experiência de lidar com o medo e, por extensão, também exacerbando esse inevitável entendimento de que temos que sobreviver a despeito da difícil experiência que vislumbramos à nossa volta. É um tempo que nos obriga a desenvolver uma grande disciplina mental, suscitando novas competências sociais. O objetivo desta abordagem é, pois, contribuir para ampliar o horizonte crítico e compreensivo sobre as possíveis alternativas que possam (de)limitar uma perspectiva de bem comum. Interessa-nos compreender como a pandemia vem repercutindo no cenário brasileiro a partir de determinados valores religiosos instrumentalizados pelos agentes da governança pública em seus discursos, decisões e liturgias. Afinal, a Covid-19, inexoravelmente, tem dado espaço a falsos profetas, de modo a contaminar os meandros da ação política, provocando o devaneio e o mal-estar na confirmação de um de nossos maiores paradoxos: a dolorosa desigualdade social.

Palavras-chave: Pandemia. Isolamento. Desigualdade social. Religião.

Abstract: In Covid-19 times, we lived the condition, never experienced, of social isolation. Paradoxically moving away from protecting ourselves as a social group. In a way, it is not wrong to say that being far away is an act of care and affection.

1 O artigo foi recebido em 29 de julho de 2020 e aprovado em 20 de setembro de 2020 com base nas avaliações dos pareceristas ad hoc.

O presente trabalho foi realizado com apoio da Coordenação de Aperfeiçoamento de Pessoal de Nível Superior - Brasil (CAPES) - Código de Financiamento 001.

2 Doutor. Faculdades EST. E-mail: gabatz12@hotmail.com

3 Doutora. Universidade Regional Integrada do Alto Uruguai e das Missões (URI), Campus Santo Ângelo/RS. E-mail: rosangelaangelin@yahoo.com.br 
The pandemic has challenged us in this difficult experience of living with fear and, by extension, it has also exacerbated the inevitable understanding that we have to survive, despite of the difficult experience, we see around us. It is a moment that forces us to develop great mental discipline, giving rise to new social skills. The objective of this approach is, therefore, to contribute to broaden the critical and comprehensive horizon of possible alternatives that may (de)limit a perspective of the common good. We are interested in understanding how the pandemic has had an impact on the Brazilian scene, based on certain religious values used by public governance agents in their speeches, decisions and liturgies. In the end, the pandemic has inexorably given rise to false prophets, to contaminate the complexities of political action, causing reverie and discomfort by confirming one of our greatest paradoxes: painful social inequality.

Keywords: Pandemic. Isolation. Social inequality. Religion.

\title{
Introdução
}

\author{
O grande desafio da existência é abrir o coração \\ e deixar que as réstias de luz iluminem nossas sombras. ${ }^{4}$
}

Esta contribuição acerca da Covid-19, assim como as demais abordagens delineadas neste dossiê, foi finalizada no confinamento. Não é de se estranhar que alguns sentimentos tenham sido recorrentes: medo, ansiedade, apreensão, desassossego. Pandemias, em geral, ampliam essa percepção de dizer mais sobre nós mesmos do que a doença em si. Em meio a múltiplas incertezas, a sociedade brasileira parece estar convivendo, como em nenhuma outra época, com o negacionismo e uma profunda crise política, que se amplia também por conta de uma assustadora falta de empatia, insensibilidade e desrespeito às milhares de vidas perdidas. ${ }^{5}$

A busca por compreender o mundo à nossa volta, sobretudo quando ele está em um processo de mudanças drásticas, é sempre um preceito desafiador. Qualquer percepção haverá de ser significativamente caracterizada por contornos pessoais, diferentes filtros, perspectivas de análise sublinhadas pela sensibilidade e criatividade humana. Diante de um estado de coisas tão complexo, não há modelos prontos. Não existem, pois, receitas para a convivência na medida em que se trata de um caminho em permanente construção. Importa, sobretudo, neste momento histórico peculiar, uma maior capacidade para compreender os medos, os gestos de solidariedade, os limites, as ambiguidades e o cotidiano que vai sendo forjado em experiências de solidariedade, resiliência e esperança. ${ }^{6}$

4 GABATZ, Celso. Percursos da Alma. Santa Rosa: Café Pequeno, 2015. p. 103.

5 FARINELLI, Victor. Bolsonaro já cumpriu o que prometeu. Opera Mundi. 02 de junho de 2020. Disponível em: <https://operamundi.uol.com.br/coronavirus/64996/bolsonaro-ja-cumpriu-o-que-prometeu-temos-30mil-mortos>. Acesso em: 31 jul. 2020.

6 LORENZINI, Daniele. Biopolítica em tempos de coronavírus. Instituto Humanitas. 14 de abril de 2020. Disponível em: $<$ http://www.ihu.unisinos.br/78-noticias/598029-biopolitica-nostempos-do-coronavirusartigo-de-danielelorenzini>. Acesso em: 30 jul. 2020. 
Nestes tempos, há, por óbvio, muitos questionamentos sobre o fato de uma grande parcela da população brasileira ignorar as orientações dos órgãos oficiais de saúde que indicam o isolamento como forma de conter a propagação do vírus. Para entender os motivos, é preciso reconhecer que, além de certos protagonistas da governança pública, existe a negação histórica do acesso a uma educação capaz de transformar corações e mentes e que, em momentos iguais ao que estamos vivendo, agrava o caos o social ${ }^{7}$, assim como, muitas vezes, questões religiosas vêm sendo instrumentalizadas pelos agentes da governança pública.

Essa negação, cunhada na estrutura de uma sociedade racista, patriarcal e de exploração, perdura por meio de nossa herança escravagista colonial, potencializada na recrudescência dessa incapacidade de aceitar opiniões divergentes, transformando o outro em inimigo e, portanto, sempre induzindo de que deveria viver em outros países, pois, talvez, não seja digno de exercitar aqui a sua cidadania. A ignorância funcional de uma camada do povo brasileiro serve a um projeto de poder de quem sempre deu as cartas neste país e que tem na mercantilização da vida humana sua principal fonte de dividendos. ${ }^{8}$

O sistema capitalista, ao promover a exacerbação do lucro, aprofunda esse rompimento da humanidade com valores essenciais ao bem comum. Nesse sentido, o desafio recorrente é encontrar meios para exercitar a cooperação e o senso de humanidade, reforçando valores como a igualdade e os princípios democráticos. É preciso desvelar o egoísmo, por vezes disfarçado de altruísmo, e questionar, sobretudo, aqueles grupos que pregam o relativismo científico. ${ }^{9} \mathrm{O}$ conhecimento científico, cumpre destacar, foi consolidado, sobretudo, a partir da importante contribuição do físico e historiador da ciência Thomas Kuhn, em sua obra seminal "A estrutura das revoluções científicas" ${ }^{\prime \prime}$.

Em linhas gerais, Kuhn afirmava que, em sua pretensão de "verdade", a ciência não dependia, como se supunha, de um núcleo comprobatório de provas científicas, cuja origem estaria em algum método de caráter cognitivo. $\mathrm{O}$ autor demonstrou, por meio de inúmeros exemplos, que regras ou métodos de investigação eram dependentes de determinados paradigmas, que mudavam com o tempo e com as próprias "descobertas" científicas e de certos "consensos" realizados pela comunidade científica.

A controvérsia em torno do uso, por exemplo, da Cloroquina, de certa maneira, extrapolou a dimensão política do campo da ciência e migrou para dimensão política do espaço social mais amplo, encontrando um fermento apropriado para o seu crescimento e proliferação: a polarização da política no Brasil [...]. O governo brasileiro perdeu - e continua perdendo, posto que não se sabe bem o rumo que a epidemia ainda vai tomar - uma excelente oportunidade de, cuidadosamente, construir um plano amplo, trans-

\footnotetext{
7 NOBRE, Marcos. Ponto-final: A guerra de Bolsonaro contra a democracia. São Paulo: Todavia, 2019.

8 SOUZA, Jessé. A elite do atraso: da escravidão à Lava Jato. Rio de Janeiro: Leya, 2017.

9 LACERDA, Marina Basso. O novo conservadorismo brasileiro: de Reagan a Bolsonaro. Porto Alegre: Zouk, 2019.

${ }^{10}$ KUHN, Thomas Samuel. A estrutura das revoluções cientificas. São Paulo: Perspectiva, 1975.
} 
disciplinar e transetorial capaz de mitigar uma série de efeitos, inclusive à economia, decorrentes da pandemia, não obstante aos exemplos que já vinham sendo observados em países onde a infecção iniciou mais cedo. ${ }^{11}$

Observa-se que as noções de empatia e solidariedade são relativizadas, mitigadas e, até, quase apagadas, quando se fala que a economia não deveria parar em razão de uma crise sanitária de ordem global. $\mathrm{O}$ que se vê com frequência em pronunciamentos dos agentes públicos e políticos é a justificativa de que a economia precisa ser preservada para que seja possível tratar a saúde pública. ${ }^{12}$ Que os efeitos de uma crise econômica seriam mais danosos que uma crise de saúde. O discurso que minimiza a gravidade da pandemia serve como propaganda no sentido de que suas indicações, ainda que inverídicas, sejam recepcionadas pelos interlocutores como verdades.

Passa a ser, propositalmente acentuada, uma narrativa com a qual se objetiva impregnar o imaginário com certas informações de modo que os interlocutores já não duvidem de alguns dados, mas os recebam como referências para suas ações. Trata-se, pois, "de uma fase na qual a irracionalidade e a falsidade objetiva se escondem atrás da racionalidade e da necessidade objetiva, a aparência torna-se total"13. Não raro, as falas de agentes políticos importantes, como Donald Trump, nos Estados Unidos da América, e Jair Bolsonaro, no Brasil, minimizando os efeitos da Covid-19, são replicadas à exaustão, de modo a ir tomando corpo, na maioria das vezes, negando a própria essência da sociedade.

\section{A busca por uma abordagem crítica}

Guardamos saudades, sensações e sentidos daquilo que fez o nosso coração bater mais forte e que tornou a vida mais bela, mais plena, cheia de sonhos. ${ }^{14}$

Cada ser humano busca encontrar, ou não, em suas crenças sociais, políticas e religiosas, alguma resposta às questões que o momento atual tem ampliado. No entanto, o que se pode observar, com mais vigor, é uma experiência comum de impotência e profundo desconhecimento acerca daquilo que o futuro nos reserva. De certa forma, junto com a Covid-19, se espalhou também a dúvida sobre a vida humana e os rumos da história. Nessa direção, é emblemática a percepção de Judith Butler: "Se certas vidas não são qualificadas como vidas ou se, desde o começo, não são concebíveis como vidas de acordo com certos enquadramentos epistemológicos, então essas vidas nunca serão vividas nem perdidas no sentido pleno dessas palavras"15.

11 RODRIGUES, Léo Peixoto. A controvérsia científica em torno da cloroquina e hidroxicloroquina no tratamento da Covid-19: a importância dos estudos sociais da ciência na sociedade complexa. Revista Simbiótica, UFES, Edição Especial, v. 7, n. 1, p. 166-167, jun. 2020.

12 DUPAS, Gilberto. O Mito do progresso ou progresso como ideologia. São Paulo: Unesp, 2012.

13 ADORNO, Theodor. Prismas: crítica cultural e sociedade. São Paulo: Ática, 1998. p. 17.

14 GABATZ, 2015, p. 146.

15 BUTLER, Judith. Quadros de Guerra: quando a vida é passível de luto? Rio de Janeiro: Civilização Brasileira, 2016. p. 13 
É como se a pandemia nos convocasse a ser diferentes, mas, ao mesmo tempo, também manifestasse uma espécie de suspeita coletiva de que estamos juntos à beira de um abismo a nos perguntar como haveremos de redimir tantas mortes, tantos desarranjos e desventuras. Seremos capazes de abraçar alguma perspectiva contrária à desesperança ou até mesmo ao desespero diante das múltiplas ameaças à vida? $\mathrm{O}$ filósofo sul-coreano, radicado na Alemanha, Byung-Chul Han ${ }^{16}$, ao refletir sobre a pandemia na Europa, nota o desespero de soberania na ação inútil de fechar as fronteiras. Para ele, o vírus isola e individualiza. Não gera nenhum sentimento coletivo forte. De alguma maneira, cada um se preocupa somente com sua própria sobrevivência. A solidariedade que consiste em guardar distâncias mútuas não é uma solidariedade que permite sonhar com uma sociedade diferente, mais pacífica, mais justa. No Brasil, o presidente conclama a população para ir às ruas e o comércio a abrir suas portas. Convivemos diariamente com a falta de compaixão por aqueles a quem tem sido negado até mesmo um gesto de luto.

A solidariedade, um dos efeitos mais desafiadores nestes tempos de obscurantismo científico, é também um sistema no qual a ação de um indivíduo tem vinculação direta com a ação dos demais. Implica a ideia de um corpo social que se organiza sob as bases de uma reciprocidade. Uma reciprocidade que se vincula a uma força transformadora na medida em que busca compreender os sentidos da coletividade, das identidades, daqueles e daquelas que fazem parte da nossa história. A solidariedade é assim um modo de relação entre sujeitos. Implica ações de cuidado, empatia, afetos com o corpo social do qual fazemos parte.

A situação atual evidencia uma espécie de necropolítica ${ }^{17}$ "à brasileira”, que se amplia pela negação das desigualdades sociais já existentes. Ocorre uma negligência da governança pública em relação aos conflitos e diferenças. A vida privada passa a ser uma janela que expõe os abismos do cotidiano. Na maioria das vezes, quanto maior a renda, maior a chance de realizar algum trabalho remoto. Na escolha entre a vida e a economia, uma parcela da sociedade, sobretudo das classes abastadas e mais pobres, compra o discurso de que é melhor continuar trabalhando ao invés de morrer de fome.

O pesquisador Wallace de Moraes propõe a categoria "necrofilia colonialista outrocida"18 com o objetivo de expressar a indisfarçável simpatia pela morte de negros, indígenas, pobres e idosos no contexto brasileiro frente à pandemia. $\mathrm{O}$ autor reitera sua premissa enfatizando ações estratégicas e arbitrárias promovidas na atual conjuntura de uma política deliberada pela morte, a simpatia e a identificação com o extermínio de quem é visto como "pária" da sociedade, o opositor, o outro, o bandido-inimigo.

${ }^{16}$ HAN, Byung-Chul. La Emergencia Viral y el Mundo de Mañana. In: VV.AA. Sopa de Wuhan. Pensamiento Contemporáneo en Tiempos de Pandemias. Buenos Aires: ASPO, 2020. p. 97-112.

${ }^{17}$ MBEMBE, Achille. Necropolítica: biopoder, soberania, estado de exceção, política da morte. São Paulo: $\mathrm{N}-1,2018$.

${ }^{18}$ MORAES, Wallace de. A Necrofilía Colonialista Outrocída no Brasil. Revista de Estudos Libertários, UFRJ, v. 2, n. 3, ed. especial, p. 1-19, jan. 2020. 
Desta maneira [...] busca marcar a discriminação, a perseguição e o amor pela morte (simbólica, psicológica e/ou física) do pobre, do idoso improdutivo, da comunidade LGBTQIA+, da mulher independente, do anarquista, do comunista, do ambientalista, do adepto das religiões de matriz não judaico-cristã, do analfabeto, do deficiente físico, daquele que atenta contra a propriedade do rico. ${ }^{19}$

Um país como o Brasil, nascido e estruturado com base em tantas situações injustas, tem produzido práticas e relações muito desiguais. Nelas, os sujeitos que sofrem a ação de precarização de suas vidas seguem os critérios de classe, raça e gênero. Precarizar vidas é torná-las também “descartáveis”. Que mais sofre os impactos do vírus são as populações diariamente submetidas a condições de vida na qual eles, de uma certa maneira, já são mortos-vivos. ${ }^{20} \mathrm{~A}$ insistência no argumento de que é preciso privilegiar o funcionamento da economia em detrimento das medidas de isolamento social soa como um evidente paradoxo. Diz-se que nossas indústrias estão com dificuldades, mas, por outro lado, se finge em não reconhecer as pessoas que estão morrendo por falta de leitos em hospitais.

Entrementes, o momento pode, de fato, nos levar para dois caminhos. Um deles, acentuado por uma maior individualização. Pessoas que possuem certos recursos financeiros e que se preocupam em salvar seus lucros, podendo, inclusive, pagar para receber tratamento se necessário for. $\mathrm{O}$ outro, de uma solidariedade mais profunda. Gente que diante da Covid-19 se permite olhar para além do seu próprio mundo. Pessoas que se organizam e se propõem a auxiliar. Gente que vislumbra o bem da coletividade. $^{21}$

Importa reconhecer que as tradicionais armaduras falharam. Os planos de saúde não foram suficientes para abafar o receio da falta de equipamentos e, tampouco, os celulares, computadores e televisões sofisticados foram capazes de entreter no meio dessa solidão sentida e vivenciada por todos e todas. A pandemia parece ser mais uma parte de um filme bastante conhecido nessa sucessão de novas doenças que irromperam nas últimas décadas. Ao mudar de forma drástica e abrupta a vida do planeta, a pandemia também oferece uma grande oportunidade para repensar escolhas. Sentimo-nos amedrontados e sozinhos. Diante de algo que não sabemos como nem quando vai acabar, vislumbramos a pequenez e a fragilidade. ${ }^{22}$

Fomos obrigados a aprender que é necessário sair dos nossos tronos, das nossas bolhas, das nossas realidades. Começamos a perceber que a doença que mata alguém de perto, também é capaz de matar quem mora do outro lado do mundo. Passamos a enxergar a importância de profissões que muitas vezes eram vistas pela lógica

19 MORAES, 2020, p. 12.

${ }^{20}$ PELBART, Peter Pál. Vida Capital: Ensaios de Biopolítica. São Paulo: Iluminuras, 2003.

21 AKERMAN, Marco; PINHEIRO, Woneska Rodrigues. "Covid-19: Não estamos no mesmo barco". Le Monde Diplomatique. 14 de abril de 2020. Disponível em: <https://diplomatique.org.br/covid-19-naoestamos-no-mesmo-barco/>. Acesso em: 29 jul. 2020.

22 HARARI, Yuval Noah. Na batalha contra o coronavirus. São Paulo: Companhia das Letras, 2020. 
capitalista como dispensáveis. ${ }^{23}$ Sentimos que a mesma solidão que se abate sobre mim angustia o meu semelhante. Alguém que tem um nome, cor, origem e religião diferentes dos meus.

O sentimento de perder o mundo pode ser coletivo e isso pressupõe o compartilhamento de um destino comum da humanidade, mas certamente não estamos todos no mesmo barco, singrando para o fim do mundo. Há transatlânticos, iates, lanchas, veleiros, escunas, caiaques, barcos a remo, jangadas e até náufragos agarrados em troncos no meio da correnteza. ${ }^{24}$

A despeito de sermos todos e todas suscetíveis ao vírus, a vulnerabilidade não deixa de ser profundamente desigual entre as pessoas. Mesmo assim, infelizmente, uma parcela da população brasileira continua vivendo em um mundo no qual esse estado de coisas lhes soa como mentira e onde, por extensão, quem diz a verdade, não raro, é visto como mentiroso. É gente que sofre, faz sofrer, destrói o que tem valor e não consegue dialogar.

Uma escolha política não significa unicamente se declarar a favor de determinado partido, ideologia ou candidato. ${ }^{25} \mathrm{Se}$ antes bastava se esconder no próprio cantinho imaginando que a situação não nos afetaria, agora, para que eu seja protegido, preciso proteger também os outros. A conta do egoísmo chegou, cara e sem nenhum desconto. Não será a cloroquina que haverá de amenizar estes tempos sombrios. Mais do que nunca necessitamos nos dar conta de que estamos conectados em redes de relações interpessoais e também institucionais. Cada indivíduo faz parte de uma elevada gama de processos, de políticas, lutas, disputas e escolhas que a todos impactam, ainda que de forma desigual ou injusta.

A verdade é que chegamos a um ponto decisivo, uma curva de inflexão na qual ou mudamos a maneira de conviver em sociedade, ou estaremos sempre à mercê de nosso próprio egoísmo disfarçado de vírus, de guerras, de crises econômicas ou governantes inescrupulosos. ${ }^{26}$ É hora de abaixar as bandeiras ideológicas e substituí-las por um pouco mais de empatia, bom senso e álcool em gel. O propósito desta abordagem é, justamente, contribuir para ampliar esse horizonte de que tempos difíceis servem para algumas coisas, entre elas, grandes aprendizados e reflexões incômodas também para as diferentes expressões religiosas presentes neste país. Interessa-nos, especialmente, perscrutar de que maneira a Covid-19 tem repercutido no cenário bra-

${ }^{23}$ PINHO, Carlos. E. S. Pandemia global, governo e desigualdade no Brasil: Um olhar das ciências sociais. Instituto Humanitas Unisinos (IHU), São Leopoldo, 12/04/2020. Disponível em: <http://www.ihu.unisinos. br/78-noticias/597877-pandemia-global-governo-e-desigualdade-no-brasil-um-olhar-das-cienciassociais>. Acesso em: 30 maio 2020.

24 AKERMAN; PINHEIRO, 2020.

25 BUTLER, Judith. El capitalismo tiene sus límites. In: VV.AA. Sopa de Wuhan. Pensamiento Contemporáneo en Tiempos de Pandemias. Buenos Aires: ASPO, 2020. p. 59-66.

${ }^{26}$ HARWEY, David. Política anticapitalista en tiempos de coronavirus. In: VV.AA. Sopa de Wuhan. Pensamiento Contemporáneo en Tiempos de Pandemias. Buenos Aires: ASPO, 2020. p. 79-96. 
sileiro a partir de determinados valores religiosos instrumentalizados pelos agentes da governança pública em seus discursos, decisões e liturgias.

O Brasil, a partir de suas peculiaridades históricas, sempre teve uma grande proximidade com movimentos religiosos. Esse fato permitiu que surgissem as condições para a emergência de um sentimento messiânico que, paulatinamente, foi estreitando sua vinculação com grupos evangélicos a partir de uma leitura bíblica que acentuava a consolidação de uma expectativa de que a nação seria abençoada se o povo e, de forma especial, o seu principal governante assumissem publicamente as verdades evangélicas. Neste sentido, o ministro das Relações Exteriores, chanceler Ernesto Araújo, ao defender as ações do governo de Jair Bolsonaro, declarou:

A pedra que os construtores rejeitaram tornou-se a pedra angular do edifício. A pedra que a imprensa rejeitou e que os intelectuais rejeitaram; que os artistas rejeitaram e os autoproclamados especialistas rejeitaram, ela tornou-se a pedra angular do edifício, o edifício do novo Brasil $^{27}$.

A imagem utilizada descortina a expectativa em um personagem que dê sustentação a essa "nova política" e um "novo Brasil". ${ }^{28}$ Trata-se de uma provocação que evidentemente sublinha uma comparação de Bolsonaro com a figura de Jesus Cristo. Aliás, desde o princípio, o governo, por meio dos seus principais interlocutores e também por meio do próprio Bolsonaro, tinha deixado evidente uma atitude reativa aos intelectuais, universidades, congresso, os meios de comunicação, entre outros setores, encarnando a figura perseguida e, na maioria das vezes, incompreendida em sua desafiadora e indigesta tarefa de transformar o Brasil em uma "Nova Jerusalém"29.

A atual conjuntura brasileira tem favorecido, sobremaneira, um fenômeno que se amplia a partir de duas perspectivas: em primeiro lugar, trata-se de compreender os contornos messiânicos do principal mandatário da nação. Grosso modo, o messianismo tem esse forte apelo para mobilizar as massas, engendrando expectativas de uma significativa parcela da população em torno de uma promessa de "salvação" diante de uma realidade descrita como "perigosa" para as "pessoas de bem". Essa situação serve como alicerce para um cenário muito favorável ao desenvolvimento do "cristofascismo". O segundo aspecto importante e, certamente, ilustrativo na crise da Covid-19 é a personificação de um presidente que se apresenta como resposta aos anseios de redenção.

No Brasil atual, a mensagem de que o Covid-19 é uma maldição impetrada pelo pecado pode ser compreendida à luz do discurso moral que dá sustentação política ao grupo no poder. Se o cristofascismo tenta aproximar Jair Messias de Jesus Cristo, seu corolário

${ }^{27}$ FOLHA DE SÃO PAULO. Chanceler compara Bolsonaro a Jesus ao chamá-lo de "pedra angular". Disponível em: <https://www1.folha.uol.com.br/mundo/2019/05/diplomaciaprecisa-ter-sangue-nas-veiasdiz-chanceler-ernesto-araujo.shtml>. Acesso em: 19 set. 2020.

${ }_{28}$ AVRITZER, Leonardo. Politica e Antipolítica. A Crise do Governo Bolsonaro. São Paulo: Todavia, 2020.

${ }^{29}$ ALMEIDA, Ronaldo de. Deus acima de todos. In: VV.AA. Democracia em risco? 22 ensaios sobre o Brasil hoje. São Paulo: Companhia das Letras, 2019. p. 23-33. 
é que contrariar o primeiro é também chamar para si e para o país a fúria do último, e, portanto, a morte. E que, ao invés das ações recomendadas pelas autoridades sanitárias, o que pode salvar o país da doença é a obediência às lideranças religiosas, especialmente aquelas alinhadas com o discurso do Executivo Federal. ${ }^{30}$

Importante salientar que a referência ao "cristofascismo", a despeito de seus eventuais limites hermenêuticos, tem a ver com o sentido atribuído ao termo pela renomada teóloga alemã Dorothee Sölle. ${ }^{31}$ A autora cunhou o termo para se referir ao fundamentalismo capaz de unir religião e política. Em seu enunciado, a palavra, simultaneamente, conseguiria abarcar algumas percepções fundamentais do fascismo em uma estreita ligação com as bases da tradição cristã. Um dos esteios do "cristofascismo" seria, justamente, o papel assumido por um líder de massas em sua relação direta com o povo, utilizando-se da religião para impor a sua vontade autocrática, combativa, autoritária, na maioria das vezes, sob a invocação de certos elementos ligados à fé cristã, adaptados aos próprios interesses, desconsiderando as instituições e o bem comum do conjunto da sociedade. ${ }^{32}$

Os evangélicos sonham com o dia em que cidade, estado e país se convertam em massa, e a terra dos tupiniquins tenha a cara de suas denominações. Afirmo que o sonho é que haja um "avivamento" religioso que leve uma enxurrada de gente para os templos evangélicos. Não reside entre os teólogos do movimento qualquer desejo de que valores cristãos influenciem a cultura brasileira. Eles anelam tão somente que o subgrupo, descendente distante dos protestantes, prevaleça. $^{33}$

O messias, assim esperado, deveria, sobretudo, mostrar seu inconformismo com os rumos da nação, da educação, cultura e costumes. Significava não contrariar o imaginário cristão conservador e, por extensão, assumir um discurso e comportamento que não fosse corrompido pela imoralidade. Esse caráter antagônico a tudo aquilo que possa divergir de uma pauta conservadora supõe a necessidade de identificar um inimigo a ser eliminado. Walter Benjamim, em suas conhecidas teses sobre o conceito de história, já referia que "em cada época, é preciso tentar arrancar a tradição do conformismo, que dela quer se apoderar. Pois o Messias não vem apenas como redentor; ele vem também como o vencedor do Anticristo"34.

Essa identificação de um suposto inimigo faz parte da narrativa de um líder totalitário. ${ }^{35}$ Sua disposição para a belicosidade e, como no caso de Bolsonaro, para

\footnotetext{
30 ARDUINI, Guilherme. Cristofascismo, pandemia e a história das epidemias no Brasil. Disponível em: $<$ https://coletivobereia.com.br/cristofascimo-pandemia-e-a-historia-das-epidemias-no-brasil/>. Acesso em: 19 set. 2020.

31 SÖLLE, Dorothee. Das Fenster der Verwundbarkeit: Theologisch-politische Texte. Stuttgart: Kreuz, 1987.

32 SÖLLE, 1987, p. 158-167.

33 GONDIM, Ricardo. Deus nos livre de um Brasil evangélico. Disponível em: < https:/www.ricardogondim. com.br/meditacoes/deus-noslivre-de-um-brasil-evangelico/>. Acesso em: 19 set. 2020.

${ }^{34}$ BENJAMIM, Walter. Magia e técnica, arte e política: ensaios sobre literatura e história da cultura. São Paulo: Brasiliense, 2012. p. 244.

35 CAMPBELL, Joseph. O herói de mil faces. São Paulo: Pensamento, 2007.
} 
a defesa incondicional de armas, a suposição acerca de uma conspiração comunista, o temor de que a família "tradicional" possa ser extinta por movimentos LGBT são manifestações que funcionam como contraponto a uma pretensa fragilidade no equilíbrio de uma sociedade cujo uso da violência e da força serve como instrumento de preservação. Esse messianismo "cristofascista" enseja uma função diante da qual se coloca como portador de uma segurança diante de possíveis ameaças a um mundo imaginário. O líder autoritário não apenas identifica o inimigo, mas, inclusive, o cria. ${ }^{36}$

Importa ainda reconhecer que nos processos políticos, como no caso do Brasil em sua última eleição majoritária, ocorreu a escolha de alguém cujo papel de "salvador da pátria" pôde ser alavancado por meio de uma maciça expectativa popular. Essa realidade acabou consolidada, seja por oportunismo ou por uma construção ideológica por vezes alheia aos fatos, mas, de toda forma, sempre coadunada no plano político em estreita vinculação com a religião. ${ }^{37}$ Soube-se explorar o imaginário popular religioso que propunha uma ordem neoliberal na economia e uma política conservadora nos usos e costumes.

O historiador francês Fernand Braudel ${ }^{38}$ caracterizou as mentalidades como prisões de longo prazo. Por isso convém observar os eventos em uma perspectiva histórica de modo que se possa ampliar o espectro de nosso olhar. Afinal de contas, é sabido que o modo de viver, conceber doenças e perceber a morte foi sofrendo mudanças que impactaram em múltiplas dimensões da vida humana. Se pensarmos que a educação como um direito social foi instituída na década de 1930, mas que tenha sido somente em 1988 que o ensino obrigatório foi assumido pela Constituição, visualiza-se o tamanho da reparação histórica que este país ainda necessita realizar com a sua população. Na medida em que a reparação histórica não se realiza, estaremos submetidos à perversidade de quem não tem nenhum pudor em garantir seus interesses. A mesquinhez expõe todo o povo e retira a possibilidade de exercitar a própria soberania. Frear qualquer avanço educacional para superar as injustiças parece não ser a preocupação de quem teria o poder de fazê-lo. ${ }^{39}$

A produção científica, que neste momento deveria receber ainda mais atenção e recursos, sofre ataques inacreditáveis e inaceitáveis. Uma vez mais as ciências humanas padecem com a desqualificação. Definir uma ciência como mais importante que outra é abandonar o pensamento científico, rumo ao obscurantismo. A Covid-19 exige que os profissionais da saúde e seus saberes sejam valorizados, mesmo que a crise que vivemos esteja longe de ser apenas sanitária. ${ }^{40} \mathrm{~A}$ crise conclama os cientis-

36 PY, Fábio. Cristofascismo à brasileira na eleição de 2018. Disponível em: $<$ https://www.cartamaior.com. br/?Editoria/Eleicoes/Cristofascismo-a-brasileira-na-eleicao-de-2018>. Acesso em: 19 set. 2020.

37 WESTHELLE, Vítor. O Deus escandaloso. O uso e abuso da cruz. São Leopoldo: Sinodal; EST, 2008.

38 BRAUDEL, Fernand. História e ciências sociais. Lisboa: Presença, 1990.

39 BADIOU, Alain. Sobre La Situación Epidémica. In: VV.AA. Sopa de Wuhan. Pensamiento Contemporáneo en Tiempos de Pandemias. Buenos Aires: ASPO, 2020. p. 67-78.

40 CORÔA, Roberta. A remoralização da saúde em tempos de pandemia: Uma esperança para o SUS. Dilemas: Revista de Estudos de Conflito e Controle Social, Rio de Janeiro, Reflexões da Pandemia 2020, p. 1-14. 
tas a dimensionar os efeitos terríveis dos tempos atuais nas relações sociais, em suas perspectivas estruturais e cotidianas.

Na presente crise humanitária, os governos [...] falharam [...] na luta contra a pandemia. Ocultaram informação, desprestigiaram a comunidade científica, minimizaram os efeitos potenciais da pandemia, utilizaram a crise humanitária para chicana política. Sob o pretexto de salvar a economia, correram riscos irresponsáveis pelos quais, esperamos, serão responsabilizados. Deram a entender que uma dose de darwinismo social seria benéfica: a eliminação de parte das populações que já não interessam à economia, nem como trabalhadores nem como consumidores, ou seja, populações descartáveis como se a economia pudesse prosperar sobre uma pilha de cadáveres ou de corpos desprovidos de qualquer rendimento. ${ }^{41}$

A Covid-19 nasceu operando um estigma contra os chineses e seus supostos hábitos alimentares. O processo se amplia em países de todos os continentes evidenciando o jogo geopolítico, inclusive do conhecimento. A desigualdade de gênero vem ganhando especial destaque nesse cenário. As pesquisas realizadas em diferentes âmbitos do conhecimento deveriam buscar a abordagem não somente desses temas, mas conclamar também para uma reflexão mais ampla.

O que a pandemia nos ensina é a necessidade de um Estado que mereça esse nome, num sentido forte hegeliano, como a efetividade da Ideia Ética. Um Estado que não seja apenas um produto frágil de empreendedores individuais, pois tal seria a definição da sociedade civil. Que seja pensado como o lugar onde o indivíduo tem a sua essência, um Estado que o proteja da morte, que invista em saúde e ciência. Sem isso, estaremos expostos não só a esse vírus, mas a outros até mais letais. ${ }^{42}$

A sociedade atual se encontra, pois, envolvida por uma crise que se evidencia em, pelo menos, três dimensões: a perspectiva da medicina (a epidemia e suas consequências sanitárias), a dimensão econômica (que se mostra com múltiplos impactos independentemente de como ou quando a pandemia venha a cessar) e a perspectiva da saúde mental (ainda pouco explorada e quase sem ser descortinada em seus desdobramentos). ${ }^{43}$

Em suma, é possível que a pandemia do coronavírus, afetando todo o gênero humano, sem distinção de nacionalidade e riqueza, gere a consciência da nossa fragilidade comum, da nossa interdependência e do nosso destino comum. É, com efeito, desejável que, para além do fragmento de um constitucionalismo planetário em termos da saúde,

${ }^{41}$ SANTOS, Boaventura de Sousa. A Cruel Pedagogia do Virus. Coimbra: Almedina, 2020, p. 26.

${ }^{42}$ BORGES, Maria de Lourdes. Sobre o mal da natureza e o mal humano. In: REICH, Evânia; BORGES, Maria de Lourdes; XAVIER, Raquel Cipriani (Orgs.). Reflexões sobre uma Pandemia. Florianópolis: Néfip online, 2020. p. 120.

${ }^{43}$ ZIZEK, Slavoj. Coronavirus es un golpe al capitalismo al estilo de "Kill Bill” y podría conducir a la reinvención del comunismo. In: VV.AA. Sopa de Wuhan. Pensamiento Contemporáneo en Tiempos de Pandemias. Buenos Aires: ASPO, 2020. p. 21-28. 
valha a pena sensibilizar para o fato de estarmos todos expostos, embora não imediata ou diretamente, a outras catástrofes graves - ambientais, nucleares, humanitárias -, cuja prevenção requer outras instituições de garantia global; por exemplo, a criação de uma propriedade estatal planetária para proteger bens comuns, como a água, o ar e as grandes geleiras e florestas; a proibição de armas nucleares e convencionais, cuja disseminação é responsável por centenas de milhares de assassinatos todos os anos; o monopólio da força militar pela ONU; e um sistema fiscal global capaz de financiar os direitos sociais à saúde, à educação e à alimentação básica, embora já proclamado em muitas cartas internacionais [...]. Parecem hipóteses utópicas [...], mas são as únicas respostas racionais e realistas para os grandes desafios de que depende o futuro da humanidade. Esta epidemia colocou na ordem do dia a necessidade de [...] uma esfera pública planetária no interesse de todos. ${ }^{44}$

Corroborando as afirmações do jurista italiano Luigi Ferrajoli, o filósofo Vladimir Safatle ${ }^{45}$ compreende que as transformações políticas efetivas não são apenas modificações nos modelos de circulação de bens e de distribuição de riquezas, são, sobretudo, modificações na estrutura dos sujeitos, em seus modos de determinação nos regimes de suas economias psíquicas e nas dinâmicas de seus vínculos sociais. Uma transformação política não muda apenas o circuito dos bens. Modifica também o circuito de afetos que produzem corpos políticos, individuais e coletivos. Por isso, para ver a força de transformação dos acontecimentos que começam a se fazer sentir, é necessário deixar-se afetar pelo que pode instaurar novas corporeidades e formas de ser. É nesse sentido que é preciso entender a liberdade não como um poder de escolher, mas, sim, reconhecer aquilo que se impõe como necessário.

É um fato relevante e, infelizmente, nem sempre levado em consideração nas análises realizadas, o aspecto de que a vida de milhões de pessoas se encontra em um processo de redescoberta diante do qual o contato físico diário passou a ser um desafio recorrente. ${ }^{46}$ Talvez o grande desafio nestes tempos obscuros seja pensar além das coordenadas do mercado e do lucro e encontrar outras maneiras de produzir e distribuir recursos tão necessários à coletividade.

Um mundo que maximize a necessidade e não o desejo das pessoas é um mundo menos frágil, mais resiliente e, aprendemos, mais feliz. Se a lição histórica que o vírus que trancou mais da metade do mundo em casa, matou centenas de milhares de pessoas e destruiu, mesmo que temporariamente, a economia mundial servirá para desenharmos um futuro diferente ainda é cedo para dizer. Porque para isso precisaremos enfrentar um inimigo ainda mais forte do que o vírus. Nossos desejos. ${ }^{47}$

${ }^{44}$ FERRAJOLI, Luigi. O Que Nos Ensina o Corona vírus? Revista Direitos Humanos e Democracia, Ano 8, n. 15, jan./jun. 2020. p. 11.

${ }^{45}$ SAFATLE, Vladimir. Um dia essa luta iria ocorrer. São Paulo: N-1, 2018. (Série Pandemia).

46 AGAMBEN, Giorgio. Reflexiones sobre la peste. In: VV.AA. Sopa de Wuhan. Pensamiento Contemporáneo en Tiempos de Pandemias. Buenos Aires: ASPO, 2020. p. 135-138.

${ }^{47}$ MOREIRA, Eduardo. A Economia do Desejo e a COVID-19. In: TOSTES, Anjuli; MELO, Hugo Filho (Orgs.). Quarentena. Reflexões sobre a Pandemia e Depois. Bauru: Canal 6, 2020. p. 64. 
É um fato importante o aprendizado com aqueles que seguem outras premissas daquelas que nos são familiares. Por extensão, ao produzir um conhecimento, é possível ser desafiado com situações e demandas, por vezes, negligenciadas pelos números e as estatísticas. A Covid-19 mostrou de maneira clara como o modelo neoliberal incapacitou o Estado para responder às situações de emergência. As respostas à crise não conseguem disfarçar uma incapacidade, uma falta de previsibilidade, uma ineficiência e pouca disposição para respaldar os valores da coletividade e do bem comum. ${ }^{48}$

Mesmo diante de uma tragédia de proporções globais, as alternativas ao modo de viver, produzir, consumir e conviver ainda parecem bastante tímidas. Infelizmente, mesmo com exemplos de uma maior preocupação com a proteção da vida em detrimento dos interesses da economia, o pretenso regresso à normalidade talvez não implique dar prioridade à defesa da vida. Será que existirá, mesmo com milhares de mortes, uma disposição para pensar em alternativas quando a alternativa que se descortina é a normalidade que se tinha antes da quarentena? É muito provável que quando os tempos de isolamento findarem, os protestos seguirão com grande intensidade, pois a pobreza e a extrema pobreza terão aumentado. Não seria surpresa se, a exemplo daquilo que se conheceu de outros períodos, os governos recorressem, outra vez, à repressão e à violência.

A nova articulação pressupõe uma viragem epistemológica, cultural e ideológica que sustente as soluções políticas, econômicas e sociais que garantam a continuidade da vida humana digna no planeta. Essa viragem tem múltiplas implicações. A primeira consiste em criar um novo senso comum, a ideia simples e evidente de que sobretudo nos últimos quarenta anos vivemos em quarentena, na quarentena política, cultural e ideológica de um capitalismo fechado sobre si próprio e a das discriminações raciais e sexuais sem as quais ele não pode subsistir. A quarentena provocada pela pandemia é afinal uma quarentena dentro de outra quarentena. Superaremos a quarentena do capitalismo quando formos capazes de imaginar o planeta como a nossa casa comum e a Natureza como a nossa mãe originária a quem devemos amor e respeito. Ela não nos pertence. Nós é que lhe pertencemos. Quando superarmos esta quarentena, estaremos mais livres das quarentenas provocadas por pandemias. ${ }^{49}$

Portanto pode-se estar nas redes sociais lamentando que o povo não esteja seguindo as diretrizes articuladas para este período ou usar deste tempo para pensar, criar novos métodos de tomada de consciência e enfrentamento da ignorância imposta por um projeto de colonização que segue firme e coeso. ${ }^{50}$ Cabe neste momento, sobretudo, questionar se este tempo também não é uma oportunidade histórica para transformar certas verdades e muitos dos nossos valores. Que tal recuperar, um pouco que seja, da empatia, da solidariedade e do amor ao próximo?

${ }^{48}$ MAGALHÃES, Juan F. L. Uma análise do liberalismo em tempos de pandemia do coronavírus: a exposição do estado de mal-estar social. Revista Estudos Libertários, v. 2, n. 3, p. 55-63, 2020.

49 SANTOS, 2020, p. 32.

${ }^{50}$ FREYRE, Gilberto. Casa grande \& senzala: formação da família brasileira sob o regime da economia patriarcal. Paris: Allca XX, 2002. 


\section{Considerações finais}

\section{Que tal se delirarmos por um tempinho. Que tal fixarmos nossos olhos mais além da infâmia. Para imaginar outro mundo possivel? ${ }^{51}$}

Em tempos de Covid-19, vive-se a condição do isolamento social. Cada qual é desafiado a não espalhar o vírus. De certa forma, não é equivocado dizer que estar longe é um ato de cuidado e de afeto. Ao entender essa premissa, tudo tende a ficar mais claro. No entanto, por vezes, a realidade tem se mostrado um pouco diferente, porque, à medida que as pessoas se afastam, também vão murchando, entristecendo. Parece faltar a luz. Assim como a semente guardada na terra necessita de luz para brotar, crescer e produzir frutos, cada um, igualmente, carece da luz do convívio, dos afetos e abraços.

O conhecido escritor português José Saramago, em seu ensaio sobre a ceguei$\mathrm{ra}^{52}$, descreve um inimigo invisível capaz de obstaculizar a visão. Uma cegueira que se espalha por uma cidade de modo a causar um grande colapso na vida das pessoas e abalar as estruturas sociais. Algo que expõe as próprias deficiências e as contradições da sociedade, trazendo à tona as desigualdades do passado, as ambiguidades do presente e a preocupação com o futuro se não houver disposição para transformá-lo.

É a Covid-19 que vem permitindo a difícil experiência de lidar com o medo e, por extensão, trazendo à tona esse inevitável entendimento de que temos que sobreviver, apesar da própria insignificância no mundo e da difícil experiência que vislumbramos à nossa volta. É este tempo desafiador que produz certas habilidades, querendo ou não, e obriga a desenvolver uma grande disciplina mental, suscitando novas competências sociais.

O isolamento faz perceber, com maior desenvoltura, que cada qual é confrontado com as próprias situações existenciais no cotidiano de suas escolhas. Como subverter a tristeza ou a depressão que se instala nas imensidões dos sentimentos, na solidão e saudade? A pandemia deixa às claras que muitas vezes não percebemos o quanto somos hostis às próprias (des)venturas e que o próprio imaginário é repleto de lugares inacessíveis, de riachos com águas turvas, vastidões divisadas por múltiplas paisagens.

Carlos Drummond de Andrade ${ }^{53}$ desafia a perscrutar caminhos nessa imperiosa necessidade de viver com o outro. Substituir a maneira de entender e sentir o mundo. Se, de um lado, uma consciência perspicaz nos desencaixa do mundo, por outro lado, ela também permite experimentar e compreender certas situações da difícil experiência de viver. Ao ter maior consciência acerca da fragilidade humana, rompe-se com certos protocolos do cotidiano. Preconizam-se novas rotinas quando cada qual

${ }^{51}$ GALEANO, Eduardo. O Direito de Sonhar, 2013. Disponível em: <https://www.youtube.com/ watch?v=QpM6W4kcnH8>. Acesso em: 02 ago. 2020.

52 SARAMAGO, José. Ensaio sobre a cegueira. São Paulo: Companhia das Letras, 1995.

53 ANDRADE, Carlos Drummond de. Sentimento do Mundo. São Paulo: Companhia das Letras, 2012. 
é, diuturnamente, alertado que agora a jornada é (de)limitada pelo vírus. No fundo, cada qual não é tão diferente assim em suas ansiedades e, portanto, não chega a ser surpreendente que indivíduos ousem seguir em alguma direção que permita, mesmo de maneira fugaz, gestos de amparo diante das ausências.

É temeroso afirmar que a Covid-19, de alguma forma, tenha igualado os seres humanos. Mais correto talvez fosse acentuar que ela dimensionou melhor algumas percepções que os indivíduos têm, por exemplo, em relação à situação do sistema de saúde no Brasil. Parece ter havido uma maior clareza sobre determinados marcadores sociais que possibilitam o acesso a tratamento de saúde para viver ou sobreviver. A pandemia, nessa direção, inexoravelmente, alimentou também alguns falsos profetas e veio a contaminar os meandros da ação política, provocando o devaneio e o mal-estar da confirmação de um de nossos maiores paradoxos: a dolorosa desigualdade social.

Essa é, entrementes, uma avassaladora constatação que, de maneira catastrófica, amplia seus tentáculos na propagação da Covid-19, pondo em evidência mais aquilo que divide do que aquilo que poderia proteger. Um mal-estar que contamina, que faz surgir a ansiedade, os estranhamentos, a agressividade e os efeitos colaterais. Poucas são as pessoas que, para além da pandemia, conseguem entender a relação de causa e efeito na qual todos e todas se encontram imersos. Talvez seja uma das primeiras vezes na história do Brasil em que é possível vislumbrar, com perplexidade, uma dinâmica de afetos e crenças na qual o supremo mandatário da nação faça pouco caso da dor e do desespero de milhares de pessoas mortas, infectadas ou lutando pela vida em situações hospitalares precárias.

A despeito de tantos infortúnios, que tenhamos a capacidade de seguir adiante a partir de uma experiência de vida capaz de tomar outros contornos por meio da esperança em dias melhores. Que cada qual tenha a capacidade de cultivar essa esperança, sem a qual os olhos, a boca e os corpos definham. Sem esperança, os olhos deixam de sorrir. Sem esperança, as bocas deixam de proclamar palavras de alento. Sem esperança, os corpos deixam de se amar. Necessitamos uns dos outros para nos sentirmos vivos, nem tanto pela felicidade que nos une, mas porque na dor nos enxergamos e conhecemos melhor. Que nunca percamos essa capacidade resiliente de subsistir a estes tempos de forma criativa e subversiva, amando e lutando pelo belo e combatendo as injustiças.

\section{Referências}

ADORNO, Theodor. Prismas: crítica cultural e sociedade. São Paulo: Ática, 1998.

AGAMBEN, Giorgio. Reflexiones sobre la peste. In: VV.AA. Sopa de Wuhan. Pensamiento Contemporáneo en Tiempos de Pandemias. Buenos Aires: ASPO, 2020. p. 135-138.

ALMEIDA, Ronaldo de. "Deus acima de todos". In: VV.AA. Democracia em risco? 22 ensaios sobre o Brasil hoje. São Paulo: Companhia das Letras, 2019. p. 23-33.

AKERMAN, Marco; PINHEIRO, Woneska Rodrigues. Covid-19: Não estamos no mesmo barco. Le Monde Diplomatique. 14 de abril 2020. Disponível em: <https://diplomatique.org.br/ covid-19-nao-estamos-no-mesmo-barco/>. Acesso em: 29 jul. 2020.

ANDRADE, Carlos Drummond de. Sentimento do Mundo. São Paulo: Companhia das Letras, 2012. 
ARDUINI, Guilherme. Cristofascismo, pandemia e a história das epidemias no Brasil. Disponível em: $<$ https://coletivobereia.com.br/cristofascimo-pandemia-e-a-historia-das-epidemiasno-brasil/>. Acesso em: 19 set. 2020.

AVRITZER, Leonardo. Política e Antipolítica. A Crise do Governo Bolsonaro. São Paulo: Todavia, 2020.

BADIOU, Alain. Sobre La Situación Epidémica. In: VV.AA. Sopa de Wuhan. Pensamiento Contemporáneo en Tiempos de Pandemias. Buenos Aires: ASPO, 2020. p. 67-78.

BENJAMIM, Walter. Magia e técnica, arte e politica: ensaios sobre literatura e história da cultura. São Paulo: Brasiliense, 2012.

BORGES, Maria de Lourdes. Sobre o mal da natureza e o mal humano. In: REICH, Evânia; BORGES, Maria de Lourdes; XAVIER, Raquel Cipriani (Orgs.). Reflexões sobre uma Pandemia. Florianópolis: Néfip online, 2020.

BRAUDEL, Fernand. História e ciências sociais. Lisboa: Presença, 1990.

BUTLER, Judith. Quadros de Guerra: quando a vida é passível de luto? Rio de Janeiro: Civilização Brasileira, 2016.

El capitalismo tiene sus límites. In: VV.AA. Sopa de Wuhan. Pensamiento Contemporáneo en Tiempos de Pandemias. Buenos Aires: ASPO, 2020. p. 59-66.

CAMPBELL, Joseph. O herói de mil faces. São Paulo: Pensamento, 2007.

CORÔA, Roberta. A remoralização da saúde em tempos de pandemia: Uma esperança para o SUS. Dilemas: Revista de Estudos de Conflito e Controle Social, Rio de Janeiro, Reflexões da Pandemia, 2020, p. 1-14.

DUPAS, Gilberto. O Mito do progresso ou progresso como ideologia. São Paulo: Unesp, 2012. FARINELLI, Victor. Bolsonaro já cumpriu o que prometeu. Opera Mundi. 02 de junho 2020. Disponível em: <https:/operamundi.uol.com.br/coronavirus/64996/bolsonaro-ja-cumpriu-oque-prometeu-temos-30-mil-mortos>. Acesso em: 31 jul. 2020.

FERRAJOLI, Luigi. O Que Nos Ensina o Coronavírus? Revista Direitos Humanos e Democracia, UNIJUÍ, Ano 8, n. 15, jan./jun. 2020.

FOLHA DE SÃO PAULO. Chanceler compara Bolsonaro a Jesus ao chamá-lo de "pedra angular”. Disponível em: $<$ https://www1.folha.uol.com.br/mundo/2019/05/diplomaciaprecisater-sangue-nas-veias-diz-chanceler-ernesto-araujo.shtml>. Acesso em: 19 set. 2020.

FREYRE, Gilberto. Casa grande \& senzala: formação da família brasileira sob o regime da economia patriarcal. Paris: Allca XX, 2002.

GABATZ, Celso. Percursos da Alma. Santa Rosa: Café Pequeno, 2015.

GALEANO, Eduardo. O Direito de Sonhar, 2013. Disponível em: $<$ https://www.youtube.com/ watch? $=$ QpM6W4kcnH8>. Acesso em: 02 ago. 2020.

GONDIM, Ricardo. Deus nos livre de um Brasil evangélico. Disponível em: <https://www. ricardogondim.com.br/meditacoes/deus-noslivre-de-um-brasil-evangelico/>. Acesso em: 19 set. 2020. HAN, Byung-Chul. La Emergencia Viral y el Mundo de Mañana. In: VV.AA. Sopa de Wuhan. Pensamiento Contemporáneo en Tiempos de Pandemias. Buenos Aires: ASPO, 2020. p. 97-112. HARWEY, David. Política anticapitalista en tiempos de coronavirus. In: VV.AA. Sopa de Wuhan. Pensamiento Contemporáneo en Tiempos de Pandemias. Buenos Aires: ASPO, 2020. p. 79-96. HARARI, Yuval N. Na batalha contra o coronavirus. São Paulo: Companhia das Letras, 2020. KUHN, Thomas Samuel. A estrutura das revoluções científicas. São Paulo: Perspectiva, 1975. LACERDA, Marina Basso. O novo conservadorismo brasileiro: de Reagan a Bolsonaro. Porto Alegre: Zouk, 2019.

LORENZINI, Daniele. Biopolítica em tempos de coronavírus. Instituto Humanitas. 14 de abril 2020. Disponível em: <http://www.ihu.unisinos.br/78-noticias/598029-biopolitica-nostemposdo-coronavirus-artigo-de-danielelorenzini>. Acesso em: 30 jul. 2020. 
MAGALHÃES, Juan F. L. Uma análise do liberalismo em tempos de pandemia do coronavírus: a exposição do estado de mal-estar social. Revista Estudos Libertários, v. 2, n. 3, p. 55-63, 2020. MBEMBE, Achille. Necropolítica: biopoder, soberania, estado de exceção, política da morte. São Paulo: N-1, 2018.

MORAES, Wallace de. A Necrofilía Colonialista Outrocída no Brasil. Revista de Estudos Libertários, UFRJ, v. 2, n. 3, ed. especial, p. 1-19, jan. 2020.

MOREIRA, Eduardo. A Economia do Desejo e a COVID-19. In: TOSTES, Anjuli; MELO, Hugo Filho (Orgs.). Quarentena. Reflexões sobre a Pandemia e Depois. Bauru: Canal 6, 2020. p. 61-64. NOBRE, Marcos. Ponto-final: A guerra de Bolsonaro contra a democracia. São Paulo: Todavia, 2019.

PELBART, Peter Pál. Vida Capital: Ensaios de Biopolítica. São Paulo: Iluminuras, 2003.

PINHO, Carlos. E. S. Pandemia global, governo e desigualdade no Brasil: Um olhar das ciências sociais. Instituto Humanitas Unisinos (IHU), São Leopoldo, 12/04/2020. Disponível em: <http:// www.ihu.unisinos.br/78-noticias/597877-pandemia-global-governo-e-desigualdade-no-brasilum-olhar-das-ciencias-sociais>. Acesso em: 30 maio 2020.

PY, Fábio. Cristofascismo à brasileira na eleição de 2018. Disponível em: < https://www. cartamaior.com.br/?Editoria/Eleicoes/Cristofascismo-a-brasileira-na-eleicao-de-2018>. Acesso em: 19 set. 2020 .

RODRIGUES, Léo Peixoto. A controvérsia científica em torno da cloroquina e hidroxicloroquina no tratamento da Covid-19: a importância dos estudos sociais da ciência na sociedade complexa. Revista Simbiótica, UFES, Edição Especial, v. 7, n. 1, p. 147-171, jun. 2020.

SANTOS, Boaventura de Sousa. A Cruel Pedagogia do Virus. Coimbra: Almedina, 2020.

SAFATLE, Vladimir. Um dia essa luta iria ocorrer. São Paulo: N-1, 2018. (Série Pandemia). SARAMAGO, José. Ensaio sobre a cegueira. São Paulo: Companhia das Letras, 1995.

SÖLLE, Dorothee. Das Fenster der Verwundbarkeit: Theologisch-politische Texte. Stuttgart: Kreuz, 1987.

SOUZA, Jessé. A elite do atraso: da escravidão à Lava Jato. Rio de Janeiro: Leya, 2017.

ZIZEK, Slavoj. Coronavirus es un golpe al capitalismo al estilo de "Kill Bill" y podría conducir a la reinvención del comunismo. In: VV.AA. Sopa de Wuhan. Pensamiento Contemporáneo en Tiempos de Pandemias. Buenos Aires: ASPO, 2020. p. 21-28.

WESTHELLE, Vítor. O Deus escandaloso. O uso e abuso da cruz. São Leopoldo: Sinodal; EST, 2008. 